\title{
PENGARUH KOMPENSASI FINANSIAL DAN NON FINANSIAL TERHADAP KINERJA KARYAWAN CV FENARU JAYA
}

\author{
RESTI RIANDI, IRSYADI ZAIN \\ Sekolah Tinggi Ilmu Ekonomi Persada Bunda \\ riandiresti@gmail.com
}

\begin{abstract}
The purpose of this study was to determine the effect of financial compensation and non-financial compensation variables on employee performance and the effect of job satisfaction on employee performance at CV Fenaru Jaya. . The method used is descriptive and multiple linear regression path analysis. From the results of the study, it is known that financial and non-financial compensation have a positive and significant effect on employee performance.
\end{abstract}

Keywords: financial compensation, non-financial compensation, performance

Abstrak: Tujuan penelitian ini adalah untuk mengetahui pengaruh variabel kompensasi finansial dan kompensasi non finansial terhadap kinerja karyawan serta pengaruh kepuasan kerja ke kinerja karyawan CV Fenaru Jaya. . Metode yang digunakan adalah deskriptif dan path analisis regresi linear berganda. Dari hasil penelitian diketahui bahwa kompensasi finansial dan non finansial berpengaruh positif dan signifikan terhadap kinerja karyawan.

Kata kunci: kompensasi finansial, kompensasi non finansial, kinerja

\section{A. Pendahuluan}

Pada umumnya, setiap perusahan atau organisasi pasti memiliki tujuan dimana perusahaan tersebut harus memiliki faktor penunjang dan pendukung untuk mencapai tujuan tersebut.Salah satu yang menjadi faktor penunjang keberhasilan perusahaan adalah sumber daya manusia.Sumber daya manusia sangat berperan penting dalam mengelola perusahaan agar tetap memiliki pencapaian tujuan yang baik. Setiap perusahaan pastinya membutuhkan tenaga sumber daya manusia yang kompeten pada suatu bidang baik itu pemimpin atau karyawan pada pola tugas serta pengawasan yang merupakan penentu tercapainya tujuan perusahaan. Kegiatan suatu perusahaan akan berjalan dengan baik apabila perusahaan tersebut memiliki sumber daya manusia yang berpengetahuan dan memiliki keterampilan serta berkeinginan dalam mengelola perusahaan seoptimal mungkin.

Salah satu faktor penting dalam upaya peningkatan kinerja karyawan adalah dengan pemberian kompensasi kepada karyawan. Pemberian kompensasi yang diberikan oleh perusahaan pada umumnya dibedakan menjadi 2 macam yaitu kompensasi finansial dan non finansial. Kompensasi finansial merupakan pemberian gaji/upah dan insentif (komisi dan bonus) setelah karyawan melakukan tugas dan tanggung jawabnya. Perusahaan wajib memberikan kompensasi finansial sebagai timbal balik atas kerja keras karyawan kepada perusahaan. Sedangkan kompensasi non finansial diantaranya adalah pelatihan, wewenang dan tanggung jawab, penghargaan atas kinerja serta lingkungan kerja yang nyaman.

CV Fenaru Jaya adalah perusahaan supplier yang lebih memfokuskan penjualan grease ke pabrik-pabrik kelapa sawit. Adapun kendala terkait kinerja karyawan adalah semakin menurunnya kinerja setiap tahunnya.Banyak faktor yang diduga penyebab tidak meningkatnya kinerja karyawan tersebut salah satu diantaranya adalah kompensasi baik secara finansial maupun non finansial. Perlu diketahui Kompensasi E-ISSN: 2657-0300 Lembaga Penelitian dan Penerbitan Hasil Penelitian Ensiklopedia $\quad 419$ P-ISSN: 2657-0319 
merupakan seluruh pendapatan dalam bentuk uang, barang langsung atau tidak langsung yang diterima karyawan sebagai imbalam atas jasa yang diberikan perusahaan. Pemberian kompensasi mencerminkan upaya organisasi dalam mempertahankan sumber daya manusia yang dimiliki sehingga mendorong karyawan untuk bekerja lebih baik lagi dan lebih produktif.

Pada Cv Fenaru Jaya terkait kompensasi seperti gaji itu sudah pasti didapatkan karena merupakan hak wajib setiap karyawan, namun terkait insentif tidak ada diperoleh oleh karyawan. Kompensasi tidak langsung berupa asuransi kesehatan dan asuransi tenaga kerja tidak didapatkan karyawan sebagai jaminan biaya kesehatan ataupun perawatan ketika terjadi kecelakaan kerja atau jatuh sakit. Karyawan juga memerlukan kompensasi non finansial berupa pemberian fasilitas gratis, rekan kerja yang menyenangkan dan lingkungan kerja yang nyaman seperti ruang tempat bekerja yang sejuk dan nyaman serta sirkulasi udara yang bagus.

\section{B. Metodologi Penelitian}

Objek Penelitian. Penelitian ini dilakukan pada CV Fenaru Jaya yang beralamat di Jl Kampar No 72 B, Pekanbaru Riau. Dalam penelitian ini yang menjadi populasi adalah seluruh karyawan tetap di CV Fenaru Jaya berjumlah 35 orang. Sampel dalam penelitian ini adalah seluruh karyawan tetap CV Fenaru Jaya. Tekhnik penarikan sampel dalam penelitian ini adalah probability sampling dengan tekhnik sensus. Metode analisis yang digunakan dalam penelitian ini adalah regresi linear berganda ( uji asumsi klasik, Uji t, uji F dan R square).

\section{Hasil dan Pembahasan}

Berdasarkan output tabel uji $\mathrm{t}$ diatas, pengujian hipotesis pertama yaitu pengaruh Kompensasi Finansial terhadap Kinerja Karyawan CV Fenaru Jaya dalam penelitian ini dapat dijabarkan bahwa setelah dilakukan uji secara parsial dimana variabel Kompensasi $\left(\mathrm{X}_{1}\right)$ berpengaruh Terhadap Kinerja Karyawan (Y), hal ini dapat dilihat pada nilai $t_{\text {hitung }}>t_{\text {tabel }}$ dengan nilai pengaruh sebesar 1,718>1,667 angka ini melebihi dari nilai yang telah ditetapkan dalam $\mathrm{t}_{\text {tabel }}$ yaitu 1,667 , dan sig. yaitu $0,003<$ 0,05

Pengujian hipotesis kedua yaitu Pengaruh Non Finansial terhadap Kinerja Karyawan pada CV Fenaru Jaya dalam penelitian ini dapat dijabarkan bahwa setelah dilakukan uji secara parsial dimana variabel Non Finansial $\left(\mathrm{X}_{2}\right)$ berpengaruh Terhadap Kinerja (Y), hal ini dapat dibuktikan pada nilai $t_{\text {hitung }}<t_{\text {tabel }}$ dengan nilai pengaruh sebesar 5,192 > 1,667, angka ini melebihi dari nilai yang telah ditetapkan dalam $t_{\text {tabel }}$ yaitu 1,667, dan sig. yaitu $0,000<0,05$.

Untuk pengujian hipotesis ketiga berdasarkan tabel hasil uji anova menghasilkan nilai $\mathrm{F}$ sebesar 21,157 dengan taraf signifikansi (0.001) yang dapat diartikan bahwa $F_{\text {hitung }}>F_{\text {tabel }}$ atau 21,158 > 3,11 dan angka probabilitas $0.000<$ dari pada 0.005 maka secara simultan dapat dikatakan bahwa Kompensasi Finansial $\left(\mathrm{X}_{1}\right)$ dan Non Finansial $\left(\mathrm{X}_{2}\right)$ berpengaruh Terhadap Kinerja $(\mathrm{Y})$ pada CV Fenaru Jaya. 


\section{Hasil Uji Determinasi $\left(\mathbf{R}^{2}\right)$}

Model Summary

\begin{tabular}{|c|r|r|r|r|}
\hline Model & R & R Square & Adjusted R Square & $\begin{array}{c}\text { Std. Error of the } \\
\text { Estimate }\end{array}$ \\
\hline 1 & $.852^{\mathrm{a}}$ & .728 & .705 & 1.617 \\
\hline
\end{tabular}

a. Predictors: (Constant), Nonfinansial, Finansial

Sumber : Data Olahan, 2021

Dari Tabel 5.32 dapat dilihat bahwa koefisiensi Adjusted R Square sebesar 0,705, hasil ini berarti variabel Kompensasi Finansial $\left(\mathrm{X}_{1}\right)$ dan Non Finansial $\left(\mathrm{X}_{2}\right)$ berkontribusi sebesar 70,5\% terhadap variabel Kinerja (Y) Sedangkan sisanya sebesar $29,5 \%$ dijelaskan oleh faktor-faktor lainnya yang tidak diteliti dalam penelitian ini.

\section{Pembahasan}

Pengaruh Kompensasi Finansial (X1) Terhadap Kinerja(Y). Dari hasil penelitian ini menyatakan bahwa kompensasi finansial berpengaruh terhadap kinerja karyawan. sehingga peneliti mendapatkan kesimpulan bahwa yang termasuk dalam kompensasi yaitu gaji/upah yang sesuai dengan pekerjaan, adanya bonus dan insentif untuk menambah penghasilan, asuransi kesehatan untuk mengcover karyawan jika terjadi kecelakaan kerja ataupun sakit, diberikannya tunjangan, dan adanya asuransi ketenaga kerjaan menjadi tabungan karyawan jika nantinya mereka sudah pensiun di tempat mereka bekerja.

Pengaruh Kompensasi Non Finansial (X2)Terhadap Kinerja (Y). Dari hasil penelitian ini menyatakan bahwa kompensasi non finansial berpengaruh terhadap kinerja karyawan. Berdasarkan angket penelitian yang telah disebarkan, peneliti mendapatkan kesimpulan bahwa kompensasi berdasarkan non finansial seperti pekerjaan, lingkungan kerja dan promosi jabatan berpengaruh terhadap kinerja karyawan.

Pengaruh Kompensasi Finansial dan Non Finansial Terhadap Kinerja. Hal ini dapat dilihat dari hasil uji $\mathrm{F}$ dan analisis koefisien determinasi yang menunjukkan bahwa kompensasi finansial dan non finansial memberikan kontribusi yang besar terhadap kinerja karyawan,. Kompensasi finasial dan non finansial yang diberikan perusahaan kepada karyawan dapat mendorong karyawan untuk bekerja lebih semangat dan lebih baik lagi sehingga pekerjaan yang telah ditentukan dapat diselasaikan sesuai target. Semakin baik penghargaan yang diberikan perusahaan ,maka semakin baik kinerja karyawan.

\section{Penutup}

Berdasarkan hasil analisis data dan pembahasan, dapat diambil kesimpulan sebagai berikut: Kompensasi finansial berpengaruh positif dan signifikan kinerja karyawan. Kompensasi non finansial berpengaruh positif dan signifikan terhadap kinerja karyawan. Secara simultan kompensasi finansial dan non finansial berpengaruh positif an signifikan terhadap kinerja karyawan.

\section{Daftar Pustaka}

Anwar Prabu Mangkunegara. 2015. Sumber Daya Manusia Perusahaan. Cetakan kedua belas. Remaja Rosdakarya:Bandung

Anwar Prabu Mangkunegara.2016. Manajemen Sumber Daya Manusia Perusahaan. Bandung: PT.Remaja Rosdakarya. 
Arikunto, S. 2002. Metodologi Penelitian Suatu Pendekatan Proposal. Jakarta: PT. Rineka Cipta.

Bangun, Wilson. 2012. Manajemen Sumber Daya Manusia. Jakarta : Erlangga Bahri, Syaiful. 2018. Metodologi Penelitian Bisnis. Yogyakarta :Andi Ofset

B. Flippo, Edwin.2016.Pengembangan Sumber Daya Manusia, cetakan kesepuluh. Jakarta : Erlangga

Hasibuan, Malayu S.P, 2011. Manajemen Sumber Daya Manusia. Jakarta: PT Bumi Aksara

Veithzal Rivai Zainal, S. 2015. Manajemen Sumber Daya Manusia Untuk Perusahaan .Edisike-7. Depok: PT Raja Grafindo

Widodo Suparno. 2015. Manajemen Pengembangan Sumber Daya Manusia.Yogyakarta: Pustaka Pelajar 